УДК 373.5:37.01-053.6

DOI:

Світлана Булавенко, кандидат педагогічних наук, докторант Інституту проблем виховання НАПН Украӥни

\title{
ОСОБЛИВОСТІ УПРАВЛІННЯ НАВЧАЛЬНИМ ЗАКЛАДОМ В УМОВАХ ФОРМУВАННЯ СОЦІАЛЬНОЇ АКТИВНОСТІ УЧНІВ
}

У даній статті йдеться про особливості інноваційної управлінської діяльності в умовах формування сочіальної активності учнів. Розкривається сутність та напрямки управлінської діяльності. Особлива увага звертається на використання інформаційно-комунікативних технологій при управлінні освітньоінформаційним простором навчального закладу спрямованого на формування сочіальної активності школярів. Докладно автор зупиняється на використанні інформаційних веб-ресурсів закладів загальної середньої освіти, який дозволяе здійснювати науково-методичний супровід учасників освітнього прочесу.

Ключові слова: інновачійна управлінська діяльність; інформачійно-комунікачійні технологї̈; освітньоінформаційний простір; сочіальна активність учнів.

Лim. 7.

Svitlana Bulavenko, Ph D.(Pedagogy), Doctoral Student of the Institute of Education Problems of the National Academy of Sciences of Ukraine

\section{FEATURES OF MANAGEMENT OF EDUCATIONAL INSTITUTION IN THE CONDITIONS OF FORMATION OF SOCIALACTIVITIES OF TEACHERS}

The article deals with the peculiarities of innovative management activity in the conditions of formation of social activity of students. The essence and directions of management activity are revealed. Particular attention is drawn to the use of information and communication technologies in the management of the educational and informational space of an educational institution aimed at the formation of social activity of students. The author dwells in detail on the use of informational web resources of institutions of general secondary education, which allows carrying out scientific and methodological support of participants in the educational process.

The coordinated work of educational and information space of the educational institution, pedagogical and student groups provides management activities on the part of the administration. The essence of management in the formation of social activity of students is the ability to plan a result, purposefully regulate the process of training and education, in the ability to choose such actions that would ensure the effectiveness of the tasks and achievement of the goal at the least cost of forces, time and resources. Among the vectors of management of the school with an innovative pedagogical system of forming the social activity of the educational curriculum, the following were identified: the implementation of the state component of the content of education, the testing of innovative projects and programs, the search for new forms and methods for organizing education; development of productive technologies of education and training; creation of own system of formation of a socially active person; development of new organizational structures and management mechanisms; current diagnosis and correction of the innovation process.

It is worth noting that the managerial activity of the head of the educational institution involves the processing of large volumes of information. In order for this information to really help to make the right managerial decisions, it must be objective, arrive on time, and reflect the dynamics of changes in the control object. Two directions of this work are defined: an introduction of information technologies in the management of the school; computerization of educational process and educational work of the institution. Creation of informational web resources of the school allows carrying out scientific and methodological support of the educational process, as well as providing timely information, exchange of opinions, virtual counseling and promotion of activities. The school information management system allows optimizing existing channels of information gathering and provides information needs of the administration and teachers.

Keywords: an innovative management activity; information and communication technologies; an educational and informational space; social activity of students.

П остановка проблеми. Сьогодні якісна освіта розглядається в наш час як один із основних індикаторів життя, інструмент досягнення соціального благополуччя, культурної злагоди й економічного зростання. Сучасна освіта характеризується низкою трансформаційних перетворень: освітня система поступово відходить від ієрархічної структури; відбувається активізація децентралізацій них процесів, результатом яких є розвиток автономного шкільного менеджменту; здійснюється переформатування управлінської діяльності; спостерігається активна взаємодія навчальних закладів з метою удосконалення, а 
значить висуваються нові вимоги до професійних і особистісних якостей керівника загальноосвітнього навчального закладу, його готовності бути лідером очолюваного ним колективу. Тож керівник навчального закладу $є$ ключовою фігурою перетворень освітнього середовища, саме він повинен визначати долю освітніх реформ, вибрати напрямок розвитку навчального закладу, впливати на педагогічну творчість кожного вчителя та створити умови для формування соціальної активності учнів [4].

Аналіз останніх досліджень. Питання управління освітою й навчальним закладом, зокрема, плануванням та організацією, як основних функцій управління розроблялась Є. Березняком, В. Бондарем, Л. Даниленко, Г. Дмитренком, Г. Сльниковою, Ю. Конаржевським, В. Лазарєвим, В. Масловим, Н. Островерховою, М. Поташником, М. Сунцовим, Г. Федоровим, Є. Хриковим та ін.

На методологічному рівні проблемами формування особистості педагога та його управлінську культуру досліджували Л. Васильченко, Г. Сльнікова, В. Лазарєв, В. Семіченко, Г. Скок та ін., теорією системного управління освітою займалися Ю. Конаржевський, Г. Сєріков та ін., особливості управлінської діяльності в освітній сфері вивчали І. Зязюн, Н. Ничкало, Л. Даниленко, Л. Карамушка, В. Симонов, Дж. Коллінз. Водночас досі питання інноваційного управління навчальним закладом в умовах цілеспрямованої педагогічної діяльності залишаються не до кінця вивченими.

Метою статті $€$ розширення наукового уявлення про управлінську педагогічну діяльність в умовах формування соціальної активності учнів.

Виклад основного матеріалу. Злагоджену роботу освітньо-інформаційного простору навчального закладу, педагогічного та учнівського колективів забезпечує управлінська діяльність 3 боку адміністрації [6].

На нашу думку, саме управлінська діяльність $\epsilon$ одним із головних чинників, що визначають результативність інноваційної роботи в закладах загальної середньої освіти. Вона вимагає, з одного боку, системності, а з іншого, - неформального підходу. Такий підхід виявляється у використанні низки інноваційних технологій, що призводить до досягнення запланованого результату. Серед векторів управління закладів загальної середньої освіти (3ЗСО) з інноваційною педагогічною системою формування соціальної активності здобувачів освіти визначили такі: упровадження державного компоненту змісту освіти, апробація інноваційних проектів і програм, пошуки нових форм і методів організації освіти; освоєння продуктивних технологій навчання та виховання; створення власної системи формування соціально активної особистості; розробка нових організаційних структур і механізмів управління; поточне діагностування та корегування інноваційного процесу.

Природно, що ефективність управління якістю навчально-виховного процесу в $33 \mathrm{CO}$ залежить від інноваційного потенціалу закладу, що характеризує здатність створювати, сприймати та реалізувати нововведення [1]. Особливість управління навчальним закладом в умовах формування соціальної активності учнів полягає в тому, що воно повинне забезпечувати не лише успішне функціонування закладу, а і його якісний розвиток в умовах оновлення освітнього процесу.

Центральною ланкою, серцевиною управління $\epsilon$ добре продуманий і створений освітньоінформаційний простір, який дає можливість успішно здійснювати навчально-виховний процес, управління ним і контроль реалізації конкретних завдань. Ефективна, раціональна організація всього шкільного життя, якісне виконання функцій усіма учасниками освітнього процесу залежить від якості, перспектив, конкретності вирішальних завдань, чіткого розподілу обов'язків і вмілої оперативної координації роботи [2].

Суть управління в умовах формування соціальної активності учнів полягає в умінні планувати результат, цілеспрямовано регулювати процес навчання та виховання, в умінні вибирати такі дії, які б забезпечували за найменших витрат сил, часу та засобів ефективність виконання поставлених завдань і досягнення мети [3]. Адже результативність навчально-виховної роботи залежить не тільки від сумлінності та майстерності окремих педагогів, а й від організованості та злагодженості діяльності всього педагогічного колективу, цілеспрямованості, зібраності, зосередженості на вирішенні основних завдань, правильності розподілу часу для формування соціальної активності школярів.

Розвиток засобів інформаційно-комунікативних технологій створили основу для широкого запровадження комп'ютерних комплексів автоматизації управління навчальним закладом [7].

Використання засобів інформаційнокомунікативних технологій в організації та плануванні діяльності 33СО має певні переваги, а саме:

- підвищення ефективності навчального процесу;

- можливість управління 3 використанням результатів попередньої діяльності; 
- ухвалення ефективних управлінських рішень;

- підвищення об'єктивності в оцінці діяльності вчителів та учнів;

- ефективне управління пізнавальною діяльністю учнів;

- ухвалення виважених рішень, що стосуються підвищення результативності навчання;

- оперативний доступ до організаційної інформації стосовно діяльності освітнього закладу;

- економія як матеріальних, так і людських ресурсів;

- вільний час на вирішення важливих питань;

- скорочення обсягу рутинної роботи [2].

Основні функції інформаційного забезпечення в управлінні навчальним закладом полягають у наступному:

- задовольняти потреби учнів, учителів, адміністрацію школи й інших структурних підрозділів в інформації, необхідної для забезпечення взаємодії між всіма учасниками навчально-виховного процесу;

- інформувати про стан освітнього процесу в навчальному закладі, про забезпеченість засобами навчання, про рівень навчальних досягнень учнів, про професійну кваліфікацію вчителів;

- передавати учням, учителям, адміністрації навчального закладу дані та документи, які стосуються їх діяльності;

- систематично виявляти рівні розвитку інтелекту, емоційно-психічного і фізичного здоров'я, освітні потреби учнів;

- інформувати педагогічних працівників про залучення батьків у процес виховання і навчання своїх дітей, інформувати про труднощі, з якими стикаються батьки [5].

Варто відмітити, що управлінська діяльність керівника навчального закладу містить у собі обробку великих обсягів інформації. Для того, щоб ця інформація дійсно допомагала приймати правильні управлінські рішення, вона повинна бути об'єктивною, надходити вчасно, відображати динаміку змін в об'єкті управління. Крім того, потрібні технології, за допомогою яких керівник зможе здійснити обробку інформації швидко і точно, з мінімальними витратами часу і сил.

Саме в цьому напрямку працює системний адміністратор навчального закладу, його завданням $\epsilon$ установка, забезпечення й координація роботи інформаційної системи, оновлення баз даних тощо. Системний адміністратор також вивчає інформаційну продукцію, яка може забезпечити ефективну роботу закладу, пропонує шляхи оптимізації інформаційної мережі управлінської ланки тощо. Адже розвиток освітньо-інформаційного простору можливий лише за умови інтенсивного запровадження інформаційно-комунікаційних технологій в управлінську та освітню діяльність навчального закладу.

Ми визначили два напрями цієї роботи: впровадження інформаційних технологій в управлінську діяльність школи; комп'ютеризація навчального процесу та виховної роботи закладу.

Перший із зазначених напрямів передбачає забезпечення оптимальних умов автоматизації робочих місць учасників освітнього процесу та використання ними програмного забезпечення, що систематизує роботу адміністрації, секретаря, психолога, соціального педагога, учителів тощо.

Другий напрям - це апробація та впровадження в навчальний процес електронних засобів навчання, розробка та застосування електронного супроводу навчальних занять, робота 3 текстовими програмними засобами та тими, які використовуються в позакласній та виховній роботі.

Доступ усіх учасників управління до інформаційного простору $33 \mathrm{CO}$ в будь-який час зі свого робочого місця став можливим завдяки мережі Інтернет, яка працює в школі й $є$ кількох рівнів: без паролю - загальнодоступна і для учнів, і для вчителів та окрема мережа для вчителів та адміністрації (вони мають пароль). Завдяки цьому накопичена інформація стала актуальною, спростився ii аналіз, у зв'язку зі своєчасним внесенням інформації до банку даних про освітній заклад полегшилось ведення статистики, процедур атестації, контролю контингенту, створено єдиний банк кадрів та освітніх програм тощо. Також кожен експериментальний 33СО має електронну пошту, власний сайт, підключений до мереж Фейсбук та Вайбер, метою яких є швидке і одночасне інформування всіх учасників освітньоінформаційного простору про освітні події, які відбуваються в навчальному закладі.

Як уже зазначалось, однією зі складових управлінського процесу є створення та діяльність сайту 33СО, що дає можливість без фізичних та часових затрат здійснити діагностику певного спрямування. Віртуальне діагностування потреб та запитів усіх учасників освітнього процесу сприяє правильному вибору форм та методів роботи, що сприятимуть розв'язанню проблем у реалізації завдань освітнього процесу. Розміщення матеріалів, опитувань, діагностик на сайті школи забезпечує не тільки швидку дію вчителя, але й мимоволі змушує педагога навчитись працювати 3 веб-ресурсами. 


\section{ОСОБЛИВОСТІ УПРАВЛІННЯ НАВЧАЛЬНИМ ЗАКЛАДОМ}

\section{В УМОВАХ ФОРМУВАННЯ СОЩІАЛЬНОЇ АКТИВНОСТІ УЧНІВ}

Створення інформаційних веб-ресурсів 33СО дозволяє здійснювати науково-методичний супровід освітнього процесу, також забезпечувати вчасне інформування, обмін думками, віртуальне консультування та й популяризацію діяльності. Сайт розкриває можливості тісного спілкування 3 учителями. За допомогою різноманітних віртуальних ресурсів учитель отримує методичну допомогу в зручний для нього час.

Однією з форм організації діяльності ІК-блоків $€$ автоматизований банк даних. Уся інформація, що накопичується в школі, розподіляється на зовнішню і внутрішню. Зовнішня - це директиви і нормативні документи системи управління освіти (накази, розпорядження та інше); навчальні плани і програми, суспільно-політична і науковопедагогічна інформація. Внутрішня інформація допомагає представити стан і результати навчання, виховання й розвитку учнів; діяльність учнівського менеджменту; інформацію про адміністрацію та вчителів, результати їхньої діяльності; дані про матеріально-технічну базу; інформацію про зовнішні зв'язки школи з іншими установами тощо [5].

Інформація також поділяється за часом на оперативну і стратегічну (тематичну і шкільну). Оперативна інформація має на меті миттєво виявляти відхилення в управлінні. Це ті дані, що потрібні адміністрації, для того щоб оцінити роботу закладу за день, тиждень, місяць, семестр. Стратегічна інформація - це дані про підсумки аналізу навчального року. Крім того, це комплексні програми розвитку школи, директивні документи Міністерства освіти і науки України, постанови уряду та інше [7].

Створені первинні бази даних $33 \mathrm{CO}$ постійно оновлюються, опрацьовуються, узагальнюються і піднімаються на вищий рівень у межах даної інформаційної системи управління, що спрощує процедуру оброблення статистичної звітності і $\epsilon$ основою для створення інформаційного забезпечення на кожному з рівнів управління.

Шкільна інформаційно-управлінська система дозволяє оптимізувати існуючі канали збору інформації та забезпечує інформаційні потреби адміністрації та вчителів.

Використання інформаційно-комунікативних технологій в управлінні школою є складовою розвитку освітньо-інформаційного простору, спрямованого на формування соціально активної особистості.

Освітньо-інформаційна система 33СО дає змогу: - узагальнити інформаційні потоки;

- класифікувати всю інформацію;

- забезпечити доступ до центральних баз даних;
- забезпечити обмін інформацією.

Усе це дає змогу адміністрації школи підвищити ефективність роботи. Упровадження інформаційно-комунікаційних технологій у процес управління навчального закладу дає змогу вчасно й гнучко забезпечувати управління розвитком системи освіти та цілеспрямовано підвищувати їі якість [7]. Особливо це стосується обліку, оброблення й аналізу інформації адміністрацією, яка використовує інформаційні ресурси навчального закладу за напрямками: навчально-виховна діяльність, інформаційно-методична діяльність, науково-практична діяльність, адміністративногосподарча діяльність, культурно-просвітницька діяльність, волонтерська діяльність, соціальна діяльність. Великий потік вихідних даних, довідкових матеріалів збирається та аналізується на комп'ютерах управлінського персоналу.

Щоб робота адміністрації була цілісною, необхідно постійно здійснювати ще й аналітичну та контролюючу діяльність. Моніторинг, як один із видів аналітичної інформації та діагностики, допомагає визначити пріоритети діяльності та проблеми, вчасне виявлення яких допомагає у коректуванні навчального процесу та реалізації освітніх нововведень.

Висновок. Отже, запропонована нами інноваційна система управлінської діяльності, $\epsilon$ такою, що здатна до саморозвитку та успішного формування соціальної активності учнів. Вона $\epsilon$ сукупністю пов'язаних мікропросторів, мікросередовищ, що утворюють ієрархічну систему навчального закладу, націлену на досягнення максимального освітнього ефекту та формування соціальної активності учнів. У цьому контексті освітньо-інформаційний простір для формування соціальної активності учнів, цієї педагогічної системи, повинен бути невід'ємною частиною освітнього процесу, створюватися, управлятися та функціонувати для вирішення освітніх завдань, в тому числі й управлінських.

\section{ЛІТЕРАТУРА}

1. Бех І.Д. Духовні цінності в розвитку особистості. Педагогіка і психологія. 1997. № 1(14). С. 124-129.

2. Булавенко С.Д. Освітньо-інформаційний простір для формування соціально-активної особистості. Навчально-методичний посібник. Ніжин. 2019.314 с.

3. Булавенко С.Д., Коваленко Є.І. Формування соціальної активності учнів. Навчально-методичний посібник. Ніжин. 2018. 224 с.

4. Григораш В., Касьянова О., Мармаза О. Управління навчальним закладом : навчальнометодичний посібник. Харків. 2003.160 с.

5. Дмитренко Г. А. Стратегічний менеджмент у системі освіти : навч. посібник. Київ. 1999. 176 с. 


\section{ІДЕЇ КУЛЬТУРНО-ІСТОРИЧНОГО ПДХОДУ Л. С. ВИГОТСЬКОГО В ПРОЦЕСІ ІНТЕРІОРИЗАЦЇ ГУМАНІТАРНО-ФАХОВИХЗНАНЬ СТУДЕНТАМИ-ФІЛОЛОГАМИ}

\footnotetext{
6. Канішевська Л. В. Виховання соціальної зрілості старшокласників загальноосвітніх шкіл-інтернатів у позаурочній діяльності : монографія. Київ. 2011. 368 с.

7. Управління інноваційним розвиткомзагальноосвітнього навчального закладу : моделі, соціокультурні процеси, технології : наук.-метод. посібник / Л. М. Калініна та ін. ; за наук. ред. проф. Л. М. Калініної. Київ, Володимирець. 2011.560 c.
}

\section{REFERENCES}

1. Bekh, I.D. (1997). Dukhovni tsinnosti v rozvytku osobystosti [Spiritual values in development of personality]. Pedagogy and Psychology. No. 1(14), pp. 124-129. [in Ukrainian].

2. Bulavenko, S.D. (2019). Osvitno-informatsiinyi prostir dlia formuvannia sotsialno-aktyvnoi osobystosti [An educational and information space of forming a socially active personality]. Tutorial. Nizhyn, 314 p.[in Ukrainian].

3. Bulavenko, S.D. \& Kovalenko, Ye.I. (2018). Formuvannia sotsialnoi aktyvnosti uchniv [Forming the students' social activity]. Tutorial. Nizhyn, 224 p. [in Ukrainian].
4. Hryhorash, V., Kasianova, O. \& Marmaza, O. (2003). Upravlinnia navchalnym zakladom : navchalnometodychnyi posibnyk [Management of an educational institution: an educational-methodical manual]. Kharkiv, 160 p. [in Ukrainian].

5. Dmytrenko, H. A. (1999). Stratehichnyi menedzhment u systemi osvity : navch. posibnyk [Strategic Management in the Educational System: Tutorial. Manual]. Kyiv, 176 p. [in Ukrainian].

6. Kanishevska, L. V. (2011). Vykhovannia sotsialnoi zrilosti starshoklasnykiv zahalnoosvitnikh shkil-internativ u pozaurochnii diialnosti : monohrafiia [An education of social maturity of high school students of boarding schools in extracurricular activities: monograph]. Kyiv, 368 p. [in Ukrainian].

7. Upravlinnia innovatsiinym rozvytkom zahalnoosvitnoho navchalnoho zakladu : modeli, sotsiokulturni protsesy, tekhnolohii : nauk.-metod. posibnyk [Management of innovative development of a comprehensive educational institution: models, socio-cultural processes, technologies: scientific-method. Manual]. L. M. Kalinina et al; (Ed.). L. M. Kalinina. Kyiv, Volodymyrets. 2011. 560 p. [in Ukrainian].

Стаття надійшла до редакції 21.06.2019

УДК 378. 026

DOI:

Олена Бабенко, кандидат філологічних наук, доиент кафедри романо-германських мов і перекладу Національного університету біоресурсів і природокористування України

\section{ІДЕЇ КУЛЬТУРНО-ІСТОРИЧНОГО ПІДХОДУ Л. С. ВИГОТСЬКОГО В ПРОЦЕСІ ІНТЕРІОРИЗАЩІІ ГУМАНІТАРНО-ФАХОВИХ ЗНАНЬ СТУДЕНТАМИ-ФІЛОЛОГАМИ}

У статті розглянуто ідеї культурно-історичного підходу Л.С. Виготського в прочесі інтеріоризачї гуманітарно-фахових знань студентами-філологами в їхній проекиії на освітній простір виму. Три лінії оволодіння культурою, виокремлені Л.С. Виготським, ми співвідносимо з модулями навчального плану професійної підготовки студентів-філологів, у межах яких перетворення форм спільної діяльності викладача і студентів стане запорукою успішності випускників та їхньої конкурентоспроможності на сучасному ринку npaui.

Ключові слова: культурно-історичний підхід; інтеріоризачія; інтеріоризачія гуманітарно-фахових знань; студенти-філологи; спільна діяльність викладача і студентів.

Табл. 2. Лім. 13.

Olena Babenko, Ph.D.(Philology), Assosiate Professor of the Romance and Germanic Languages and Translation Department, National University of Life and Environmental Sciences of Ukraine

\section{S. VYGOTSKY'S IDEAS OF CULTURALAND HISTORICALAPPROACH IN THE PROCESS OF INTERNALIZATION OF STUDENTS-PHILOLOGISTS' HUMANITARIANAND PROFESSIONAL KNOWLEDGE}

This paper outlines basic ideas of L. S. Vygotsky's cultural-historical approach, in particular, the ideas about person's development as the mastery of culture, raising human beings, correlation of learning and development in the zone of proximal development. The emotional background in the zones of current, potential and proximal development is described in comparison. Parameters of the child's development and their comprehension in different scientific conceptions are highlighted. L.S.Vygotsky's theoretical concepts are systematized.The implementation of this approach is impossible without internalization. Students' skills and knowledge are transformed from the social plane into the cognitive plane during this process. The internalization of philology students' humanitarian and 